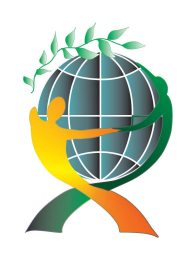

\author{
(online) $=$ ISSN $2285-3642$ \\ ISSN-L = $2285-3642$ \\ Journal of Economic Development, Environment and People \\ Volume 7, Issue 4, 2018
}

URL: http://iedep.spiruharet.ro

e-mail: office jedep@spiruharet.ro

\title{
Employee Performance Analysis to Increase the Profitability; Case Study at PT XYZ, BEKASI-WEST JAVA
}

\author{
Budi Satria $^{1}$, Nur Amega Setiawati ${ }^{1}$ \\ ${ }^{1}$ Indraprasta University, Jakarta-Indonesia
}

\begin{abstract}
The purpose of this study was to analyze the performance of PT XYZ employees engaged in ceramics. Seeing strong business competition, the development of human resources is very important in increasing the productivity of the company. The research was conducted in three divisions namely Plant, Accounting and Finance and Marketing. The results showed that the achievement of the objectives of each Division was quite good / high, especially the Plant division. This is because the SOP that is applied is almost completely implemented, besides that the supervision system is run properly so that it can create a comfortable working atmosphere for employees.
\end{abstract}

Keywords: Employee Performance, Operational Management, Indonesia, West Java

\section{JEL Codes: 129}

\section{Introduction}

Human resources are one source of competitive advantage and key elements that are important for achieving success in competing to achieve goals. Therefore, the management of human resources for the organization is important for service the community (Susilowati et al, 2013). The study of the relationship between HR management and organizational performance was found in research conducted by MacDuffie (1995) and Zacharatos et al. (2005) where both enter aspects of HR management as part of the overall aspects of production management, before being linked to organizational performance.

Human resources are an important matter in any business activity, because the quality of these things is very determining in the performance of a company. Widarsono (2009) states that Human Resources (HR) have a very important role that influences the success of the company in facing global markets and competition management and development of human resources, is an investment for the company because it requires costs to support it, but in line with this in mind, the benefits gained by the company are also great because the workers and employees who are owned, become professional and reliable in doing all the work in the company (Limawandoyo et al, 2013). Three main concepts in the human resource strategy are also presented by Cahayani (2005), which includes competitive advantage, special capabilities and suitability of strategies. 


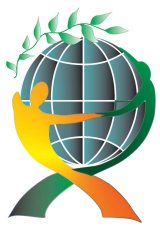

\author{
(online) $=$ ISSN $2285-3642$ \\ ISSN-L = $2285-3642$ \\ Journal of Economic Development, Environment and People \\ Volume 7, Issue 4, 2018
}

URL: http://iedep.spiruharet.ro

e-mail: office jedep@spiruharet.ro

Humans are always active and dominant in every organizational activity, because humans become planners, actors and determinants of the realization of organizational goals. Goals cannot be realized without the active role of employees even though the tools owned by the company are so sophisticated. Sophisticated tools owned by the company have no benefit for the company if the active role of employees is not included. Managing employees is difficult and complex, because they have heterogeneous thoughts, feelings, status, desires, and backgrounds brought into the organization. Employees cannot be fully regulated and controlled such as managing machines, capital, or buildings. A human resources department must have the ability to develop, use, and maintain human resources so that organizational functions can run in a balanced manner (Sedarmayanti, 2009).

Today, many managers in various industries think of better ways to measure company performance. These measurements can be used to assess the success of a company. The old (traditional) measurement model, namely the measurement by looking at the results of the performance of an organization described in the financial statements, is felt to be unusable because the financial statements as a performance benchmark are no longer able to describe the company's strategic points. So it is necessary to have research on how to measure performance in a comprehensive, integrated and balanced manner in accordance with the company's objectives. According to Mardatillah et al. (2001), in the development of new organizations and economics, the creation of the value of an organization is dominated by HR and other intangible assets, therefore it is necessary to measure HR strategies.

As an object of research, researchers chose PT XYZ, a ceramic factory established in Bekasi, West Java. The object of research is interesting, considering the competition in Indonesia's ceramic market is very high, so it demands productive human resources to be able to achieve the company's targets.

\title{
2. Methodology
}

The population in the study were all plant division employees, accounting and finance, marketing at PT $X Y Z$. Totally 21 people. Because the population is relatively small, the research method uses a census method where all employees of the plant division; accounting and finance; and marketing at PT XYZ was used as a respondent in the study. The distribution of the number of employees in each division are:

Table 1. Distribution of samples

\begin{tabular}{lll}
\hline No & Division & Amount \\
\hline 1 & Plant & 6 \\
\hline 2 & Accounting and Finance & 3 \\
\hline 3 & Marketing & 12 \\
\hline Total & & 21 \\
\hline
\end{tabular}




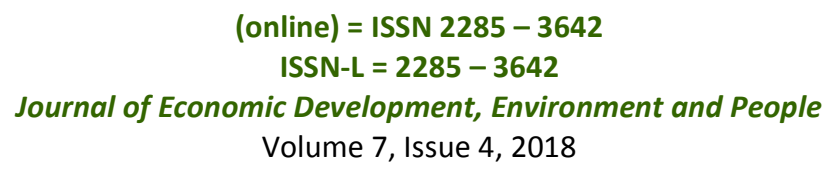

The research instrument consists of four aspects including the following:

1 Certain employee characteristics such as attitude, appearance and initiative are the basis for evaluation.

2 Competencies. Competence consists of knowledge, skills, traits and behaviours, and is related to interpersonal or business-oriented skills.

3 Achieving goals. If the organization considers the end result of achieving the goal as meaningful, the outcome of achieving the goal will be the right factor to be evaluated to be compared with the standard.

4 Increased potential. When organizations evaluate employee performance, the criteria are focused on the past, the present, compared to the standards.

\section{Result And Discussion}

Based on each supervisor's assessment of his staff, the results are shown in Table 2, below,

Table 2. Recapitulation of Employee Assessment

\begin{tabular}{|l|l|l|l|}
\hline Aspect & Plant & $\begin{array}{l}\text { Akunting dan } \\
\text { Finance }\end{array}$ & Marketing \\
\hline Social Attitude & 4 & 3,7 & 4,4 \\
\hline Performance & 4,3 & 4,3 & 4 \\
\hline Initiative & 4,5 & 4,7 & 3,9 \\
\hline Knowledge & 4,3 & 3,3 & 4,4 \\
\hline Skill & 4,5 & 4,3 & 4,7 \\
\hline Attitude on Work & 4,8 & 4 & 3,9 \\
\hline Behaviour & 4,3 & 4 & 4,2 \\
\hline Interpersonal skills & 3,8 & 3,3 & 4,5 \\
\hline Business Orientation & 4 & 4,7 & 4,2 \\
\hline Productivity Y-1 & 4,8 & 4,7 & 3,4 \\
\hline Productivity Y & 4,5 & 4,7 & 4,4 \\
\hline
\end{tabular}

Source : Data processed, 2018

Based on table 2, it can be observed that the average performance of each employee, in each division, is categorized as Good (Score 4). Thus it can be concluded that the performance of the four divisions is quite good and can support the company activities in achieving its objectives. Figure 2 below shows the strengths of each aspect of the supervisor's assessment. 

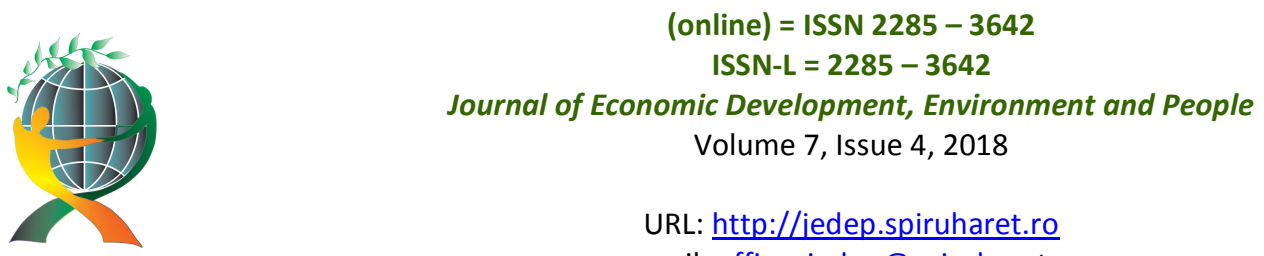

URL: http://iedep.spiruharet.ro

e-mail: office jedep@spiruharet.ro

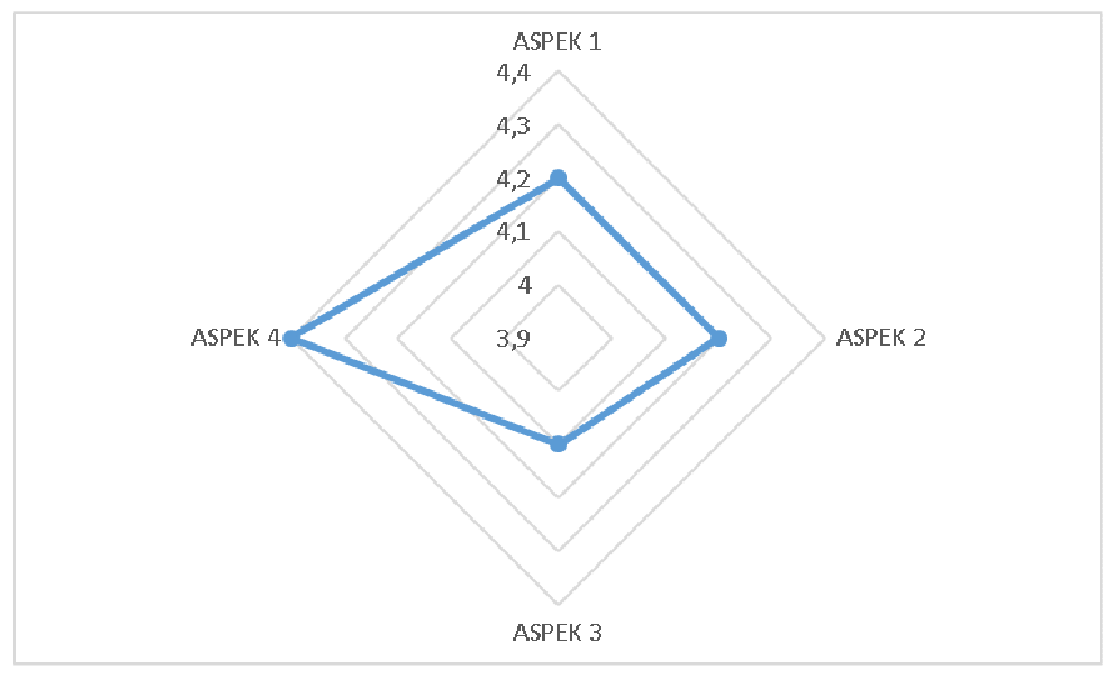

Fig 1. Assesment Per Aspect

Source: Data processed 2018

Figure 2 shows that the greatest strength of employees is in the fourth aspect, namely the productivity of this year and the previous year $(\mathrm{Y}-1)$. While the lowest aspect is the third aspect, namely business orientation and interpersonal skills.

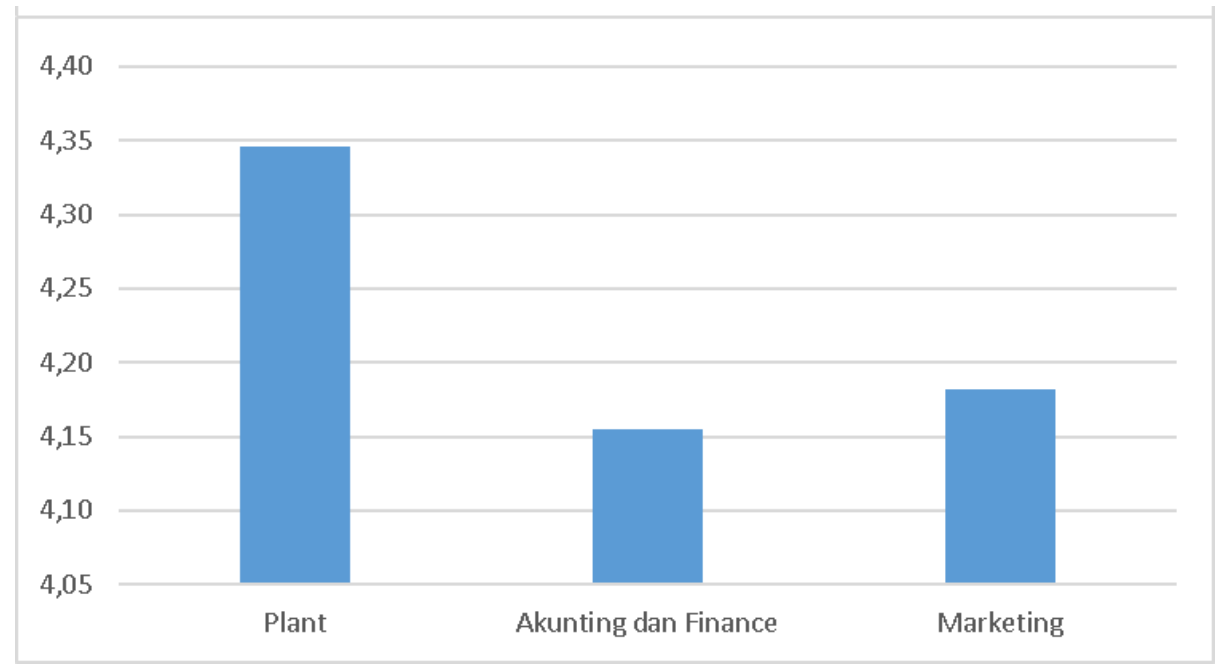

Fig 2. Assesment Per Division

Source: Data processed 2018 


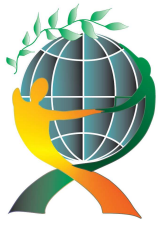

\author{
(online) $=$ ISSN $2285-3642$ \\ ISSN-L = $2285-3642$ \\ Journal of Economic Development, Environment and People \\ Volume 7, Issue 4, 2018 \\ URL: http://iedep.spiruharet.ro \\ e-mail: office jedep@spiruharet.ro
}

Based on the above results it can be seen that there is a difference in score in the Division, where the Plant Division gets the highest rating (4.35), then the second is the Marketing Division (4.18) and finally the Division of Accounting and Finance (4.15). But these calculations shows that there is no significant difference between performance in each Division. The assesment of each Division is in the High/Good category (Score 4), so it can be concluded that the employee's performance is quite good and ready to support the strategy and goals of the company.

\title{
4. Conclusion
}

Based on observations and questionnaires of the research, it can be concluded that: Evenness of skills is needed so that each division can run optimally and can work well, so the company needs to add training activities for employees. In each Division, the achievement of goals is quite good /high, especially the Plant division. This is because the SOP that is applied is almost completely implemented, besides that the supervision system is run properly so that it can create a comfortable working atmosphere for employees. It still has the same direction (advancing Betawi culture).

\section{References}

[1] Cahayani, Ati. (2005), Strategi dan Kebijakan Sumber Daya Manusia, PT. Indeks. Anggota IKAPI: Jakarta.

[2] Limawandoyo, E.A., Simanjutak, A. (2013), Pengelolaam Dan Pengembangan Sumber Daya Manusia Pada PT Aneka Sejahtera Engineering, Jurnal Manajemen Bisnis Perta, 1(2), pp.1-12.

[3] MacDuffie, J.P, (1995), Human Resource Bundles and Manufacturing Performance: Organizational Logic and Flexible Production Systems in The World Automotive Industry, Industrial \& Labour Relations Review, 48 (2), pp. 197-221

[4] Mardatillah, Y.I., Nasution, H., Ishak, A. (2013), Evaluasi Kinerja Manajemen Sumber Daya Manusia PT XYZ Dengan Human Resource Scorecard, e-Jurnal Teknik Industri FT USU, 1(1), pp. 23-27.

[5] Susilowati, P., Hatagaol, P., Pasaribu, B., Djohar, S. (2013). Pengaruh Aspek Pengelolaan Sumber Daya Manusia terhadap Peningkatan Kinerja Organisasi di Industri Otomotif di Indonesia, Jurnal Manajemen Teknologi, 12(1), pp. 21-39.

[6] Sedarmayanti, (2009), Sumber Daya Manusia dan Produktivitas Kerja, CV. MandarMaju, Bandung.

[7] Widarsono, Agus, (2009), Human Resources Scorecard; Linking People, Strategy And Performance (Suatu Model Pengukuran Kinerja SDM), Fakultas Pendidikan Ekonomi \& Bisnis Universitas Pendidikan Indonesia (UPI BHMN): Bandung

[8] Zacharatos, A., Hershcovis, M.S., Turner, N., and Barling, J. , (2007), Human Resource Management in The North American Automotive Industry: A Meta-Analytic Review, Personnel Review, 36 (2),pp.231-254. 